\title{
Socialist Republicanism
}

\author{
Tom O'Shea
}

Forthcoming at Political Theory. Please cite published version.

\section{Introduction}

The republican demand for the abolition of endemic domination cannot be met without a radical transformation of economic life. Our best hope of securing this, so I shall argue, is a socialist programme. Conversely, republicanism offers a compelling account of unfreedom under capitalism, which socialists can use to articulate their own emancipatory ambitions. Thus, there is good reason for both socialists and republicans to pursue a socialist republicanism.

Socialism and republicanism can, however, seem like odd bedfellows. The civic republican tradition has often been denounced as aristocratic and elitist, with an ingrained suspicion of democratic rule. ${ }^{1}$ Ancient republicans were willing to accept the subordination of slaves, women, and foreigners as the price to be paid for the liberty of male citizens. ${ }^{2}$ So too, these republicans inveigh against property taxes, while telling us that the function of citizenship is the defence of property. In the modern era, republicans have denied such citizenship to those who lack economic independence, as well as asserting the rights of masters over their servants. Furthermore, some contemporary civic republicans advocate curbs on the power of labour unions and champion competitive markets as a way to reduce domination. Republican political thought is not, then, the most obvious partner for socialist movements. ${ }^{3}$ The feeling can also be mutual, with the revolutionary hopes and collectivist orientation of many socialists likely to trouble those civic republicans who are committed to the rule of law and wary of majoritarianism. ${ }^{4}$ 
Nevertheless, recent work in the history of political thought is showing the two traditions need not be at loggerheads, and can instead provide complementary diagnoses and remedies for the ills of capitalist societies. This radical republican history has found its most successful expression in republican readings of Marx and the recovery of a nineteenth century labor republican movement..$^{5}$ We shall also see there is an overlooked republican thread running through early twentieth century socialism in Britain and the United States. The retrieval of this radical history of republicanism has been taking place alongside contemporary republican arguments for workplace democracy, the right to strike, and a political economy hostile to laissez-faire capitalism. ${ }^{6}$ Can these radical republican materials be used to construct an attractive, theoretically incisive, and defensible political philosophy?

My aim is to show how a socialist republicanism fulfills this ambition. Indeed, I shall argue that the socialist goal of public ownership and control of the means of production is the most promising institutional foundation for a society which suppresses domination and enables popular government over our social and economic life. In short, the path to a mature republicanism should also lead us to socialism. Conversely, republicanism offers socialists an astute understanding of freedom, which puts talk of 'wage-slavery' and 'economic despotism' on a firm theoretical footing, while opening up a richer vision of the lineaments of a free society.

In order to establish the compatibility and complementarity of republicanism and socialism, we first need some grasp of their central commitments. Classical republicans lauded the liberty of a citizenry which was neither subject to external rule nor under the power of a tyrant. Absolutism was rejected for mixed government, and the republican polity was to be underpinned by both the rule of law and political institutions fostering active citizens committed to the common good rather than their own private or factional interests. ${ }^{7}$ The touchstone of contemporary republicanism has been the adoption of a neo-roman conception 
of liberty which contrasts freedom with a condition of domination, in which someone falls under the arbitrary power of a master. This allows neo-republicans to identify unfreedoms which do not take the form of outright interference, and which instead arise from someone's vulnerability to power which can be exercised over them with impunity, even if it is presently held in reserve. Thus, the slave who must always be mindful of her master's power is unfree, whether or not the master happens not to his enforce his will, because she acts only at his indulgence rather than under her own singular power.

Turning briefly to socialism: it implies both social control over the means of production and a commitment to egalitarian political democracy. I do not want to be too prescriptive at this initial stage, but when we return to the nature of this social control, I shall defend a further specification of socialist commitments in contradistinction to left-liberal alternatives such as property-owning democracy.

A socialist republicanism which fuses these two traditions must first reckon with conservative tendencies in classical republican thought. I shall, however, argue that republican support for private property, political disenfranchisement, and market-based solutions to domination is far from indispensable. Conversely, the relatively neglected radical history of republicanism provides powerful conceptual resources for critiquing capitalism and revealing the prerequisites of an emancipated society. I contribute a further chapter to this emerging story by showing how early twentieth century socialists in America and Britain reached for a republican vocabulary to condemn the economic subordination of workers. The foregoing radical history then informs a socialist republicanism which takes public ownership and economic democracy to be foundations for a society truly capable of subduing dominating power. I defend this approach from both the Marxist objection that it overlooks the impersonal nature of domination under capitalism and the left-liberal objections that milder measures of worker codetermination or property-owning democracy are sufficient to suppress dominating 
relationships. Finally, I outline proposals for moving towards a socialist republicanism without simply substituting public domination for private domination. The resulting socialist republicanism identifies the need for more ambitious institutional grounds for republican liberty than is often supposed, while offering us a distinctive emancipatory justification for socialism.

\section{Reactionary Republicanism?}

The first major obstacle to socialist republicanism is the charge that the republican tradition is irredeemably reactionary. John McCormick tells us, "Republicanism, in ancient and modern political theory and practice, guarantees the privileged position of elites more than it facilitates political participation by the general populace". ${ }^{8}$ Considering the writings of ancient republicans like Cicero can help confirm this gloomy view, since he arraigns himself against property taxes - a measure which would lessen socioeconomic inequality. ${ }^{9}$ Furthermore, he opposes both agrarian reform and debt forgiveness on the grounds that they would be unfair and disrupt civic concord, thereby undermining the foundations of political community. Cicero concludes, "it is the proper function of a citizenship and a city to ensure for everyone a free and unworried guardianship of his possessions". ${ }^{10}$

McCormick's concerns about explicitly political participation also have some foundation. Take James Harrington's division of the populace into those "freemen or citizens", who "live of themselves", and "servants" who live in servitude to others. The condition of the latter is taken to be "inconsistent with freedom or participation of government in a commonwealth." ${ }^{11}$ Here we see the economically dependent being politically disenfranchised.

Algernon Sidney not only shares this political commitment but furthermore defends private economic power. ${ }^{12}$ After assuring us that so long as no harm is done to the public, "I 
am protected in the peaceable enjoyment and innocent use of what I possess", he claims that "if there be a contest between me and my servant concerning my service, I only am to decide it: He must serve me in my own way, or be gone if I think fit, tho he serve me never so well". ${ }^{13}$ Sidney is here championing what we would now call 'at-will employment', while affirming the residual authority of employers.

Are such economic commitments a relic of early modern political thought which fall away in an avowedly egalitarian neo-republicanism? The recently articulated commercial republicanism of Robert Taylor suggests not, since he explicitly endorses a "move to right-towork laws and universal at-will employment" in order to eliminate "closed-shop unionism and related 'for cause' dismissal", which he takes to expose employers to "union abuse". ${ }^{14}$ This underpins market-led strategies for reducing domination, with Taylor arguing, "a republican economic program should be primarily focused on promoting competitive conditions", since "perfect competition is a translation of the rule of law into the economic sphere". ${ }^{15}$

While Taylor's position is an outlier in contemporary republican economic thinking, it shares some of the market-friendly sentiments of the leading republican political philosopher, Philip Pettit, who insists, "far from threatening republican freedom, the market can reduce dependency and domination". ${ }^{16}$ For instance, Pettit explains that "in a well-functioning labor market $[\ldots]$ no one would depend on any particular master and so no one would be at the mercy of a master: he or she could move on to employment elsewhere in the event of suffering arbitrary interference". ${ }^{17}$ Likewise, he warns us of the danger to "small entrepreneurs" who are "held to ransom by the primary or secondary picketing of a powerful trade union that can put them out of business". ${ }^{18}$

Why then should socialists take a second look at a republican tradition whose members have variously defended the security of private property, political disenfranchisement of the economically dependent, at-will employment, and market society, while disdaining property 
taxes, land reform, debt cancellation, and strong labour unions? In short, none of these commitments are integral to intelligibly republican political thought.

Consider again Cicero's discussion of property. Would socialising property amount to a failure to ensure each citizen "free and unworried guardianship of his possessions", in ways raising republican concerns about domination? While the capacity to dispossess someone can readily seem like dominating power, the ability of a community to expropriate private property is not inevitably arbitrary. When the members of an association can impose legislation on themselves redistributing or socialising property in pursuit of their common interests, subject to procedural safeguards, vigorous institutional oversight, and democratic accountability, without thereby immiserating its original owners, then such a power is drained of much of its potentially dominating character (although, as we shall see, further safeguards are needed to sufficiently minimise public domination by the state).

Nor do republicans have to endorse disenfranchisement of economic dependents. Harrington and Sidney are right to identify a tension between subordination to others and free citizenship, since you do not possess perfect political liberty when those who support you economically can also impoverish you if they dislike your behaviour. But an egalitarian republicanism will look to measures to eliminate or reduce the original economic vulnerability rather than recommending disenfranchisement.

Finally, nothing in the republican approach demands market-based measures: their desirability for republicans depends on whether they curb domination. We shall see shortly that there are radical republican grounds for deep scepticism about the use of markets to organise central areas of human concern like labour and housing. Nevertheless, Sam Gindin's comments on the place of markets under socialism are salutary: 
praising the voluntary and efficient nature of markets apart from the underlying social relations in which they're embedded fetishizes markets. But markets are also fetishized when they are rejected as an absolute and treated as having a life of their own independent of those underlying relations. ${ }^{19}$

The same lesson goes for socialist republicanism. While markets do not have to be baked into a republican political economy, they may have a circumscribed place in a socialist republican prospectus in circumstances when they could provide a valuable depersonalisation and diffusion of economic power.

\section{Radical Republicanism}

Republicanism need not be fundamentally reactionary. Yet, are there reasons to identify positive affinities between socialism and republicanism? Historians of political thought are uncovering a rich seam of nineteenth-century radical republicanism that shows how republican ideas have been used to critique the unfreedom of workers in capitalist societies. ${ }^{20}$ For instance, some affinity with republicanism is intimated by Marx's prodigious use of the language of slavery to characterise the condition of workers, his description of the English peasantry as "a servile rabble dependent on the arbitrary will of the landlords", and defence of a "Social Republic" in which the power of the capitalist and landowner class is supplanted by the Commune. $^{21}$

Stronger evidence can be found in the deep structure of much early socialist thought. Bruno Leipold has drawn attention to Auguste Blanqui's claim that the usurpation of productive property by the rich means that workers, 
though not condemned to remain slaves of any given individual, nevertheless become absolutely dependent on that caste, since their only remaining freedom is the choice of which master will rule over them ${ }^{22}$

Similarly, Engels tells us that the worker is "not the slave of a particular individual, but of the whole property-holding class" to whom "he is forced to sell himself" piecemeal. ${ }^{23}$ Marx too points to the "absolute dependence of the working class upon the capitalist class". ${ }^{24} \mathrm{We}$ encounter here a class-based conception of dominating dependence which results from falling within the power of a dominating group rather than subjection to a single powerful individual.

Personal domination between individuals does not fall out of this picture, however, since class domination creates conditions in which it thrives. While workers are said to be "slaves of the bourgeois class", Marx and Engels claim their enslavement is "above all, by the individual bourgeois manufacturer". ${ }^{25}$ More darkly, Engels recapitulates the structure of the republican analysis of domination when he describes the effective jus primae noctis of the master in the factory, whose indiscriminate power to fire the girls working for him enables not only economic but sexual exploitation: "his mill is also his harem; and the fact that not all manufacturers use their power, does not in the least change the position of the girls." ${ }^{26}$ In other words, the girls are dominated even if the master chooses not to abuse his arbitrary power. Thus, we see the translation of class domination into personal domination of individual workers by individual proprietors.

Thinkers associated with the Knights of Labor in late nineteenth-century North America have an even stronger republican pedigree. ${ }^{27}$ Their Journal of United Labor even recycles lines from Sidney:

SLAVERY - The weight of chains, number of stripes, hardness of labor, and other effects of a master's cruelty, may make one servitude more miserable than another; but 
he is a slave who serves the gentlest man in the world, as well as he who serves the worst; and he does serve him if he must obey his commands and depend upon his will. ${ }^{28}$ In a similar vein, the Journal also tells us, "when a man is placed in a position where he is compelled to give the benefit of his labor to another, he is in a condition of slavery, whether the slave is held in chattel bondage or in wages bondage, he is equally a slave." ${ }^{29}$ Wage-slaves had more latitude than chattel slaves, but were still rendered unfree by their systemic dependence on the owners of productive assets like land and tools. Workers in the new industrial economy were thus said to have been "driven, from necessity" to sell their labour to these owners. $^{30}$

Alex Gourevitch coins the term 'structural domination' to describe this phenomenon. He says: "Structural is the appropriate word [for the domination of these workers] because it was a form of domination arising from the background structure of property ownership and because the compulsion they felt did not force them to work for a specific individual." ${ }^{31}$ Structural domination happens when someone's socio-structural position leaves them without a reasonable alternative to being subjected to a master. ${ }^{32}$ In structural domination, "an unequal structure of control over productive assets" leads to workers being "dominated by a number of agents, but not any single, given agent in particular." ${ }^{33}$ So understood, structural domination compels the worker into a contract of employment, and then the arbitrary power of a particular boss leaves them personally dominated once they are so contracted. To avoid this, 'labor republicans' proposed and implemented forms of cooperative labour, intended to make workers their own masters, rather than subordinating them to the authority of the owners of productive assets. ${ }^{34}$ Despite some remarkable successes in the late nineteenth century, these attempts at building a 'cooperative commonwealth' eventually fizzled out along with the Knights of Labor themselves. 
It is seldom noticed that the republican influence on radical politics does not end here, and instead continues into the twentieth century. Consider Eugene Debs - the five-time Presidential candidate for the Socialist Party of America. We find republican language peppering much of his writing and speeches from the first decade after the turn of the century:

the great mass struggle in economic servitude. The working class are dependent upon the capitalist class, who own machines and other means of production; and the latter class, by virtue of their economic mastery, are the ruling class of the nation, and it is idle under such conditions to claim that men are equal and that all are sovereign citizens. No man is free in any just sense who has to rely upon the arbitrary will of another for the opportunity to work. Such a man works, and therefore lives, by permission, and this is the present economic relation of the working class to the capitalist class. ${ }^{35}$

Republican tropes of servitude, dependency, citizenship, and reliance upon the arbitrary will of another are unmistakable here. Debs also stressed that political equality was impossible while workers lacked economic freedom, again understood as when such a worker "is at the mercy of his master since he depends upon his arbitrary will for the opportunity to labor". Thus, he concludes, "a political republic and an economic despotism are incompatible and in ceaseless conflict". 36

Debs echoes labor republican demands to "engraft republican principles into our industrial system", as well as the attempts of British socialists to characterise economic domination by drawing parallels with political autocracy. ${ }^{37}$ For example, Beatrice and Sidney Webb decry "the uncontrolled power wielded by the owners of the means of production", which for the worker meant "a far more genuine loss of liberty, and a far keener sense of personal subjection, than the official jurisdiction of the magistrate, or the far-off, impalpable rule of the king". ${ }^{38}$ This critique is carried forward, in what is sometimes strikingly republican language, by later British socialists. R. H. Tawney, for instance, observes that an employer's 
power over property can ensure that workers "live, in effect, at the will of a lord", and Philip Snowden likewise tells us, "There can be no real liberty so long as men are dependent for their means of living upon the goodwill or caprice of a private employer". ${ }^{39}$ Socialist republican arguments and vocabulary therefore survive well into the twentieth century.

\section{Domination and Market Discipline}

We have encountered strong historical grounds for aligning socialist and republican thought, especially insofar as republican opposition to subjection to another's arbitrary will could be extended to encompass economic domination rooted in class. But does concentrating narrowly on domination risk ignoring one of the central theoretical innovations of Marxism: namely, a renewed focus on the impersonal dynamics of capitalism, which supplants a fixation on the arbitrary will? Marx observes that "as a whole", conditions for workers do not "depend on the good or ill will of the individual capitalist", but rather "the inherent laws of capitalist production, in the shape of external coercive laws having power over every individual capitalist". ${ }^{40}$ In the same spirit, Nicholas Vrousalis objects to republican critiques of capitalism on the grounds that "domination without arbitrariness" is common in modernity. ${ }^{41}$ Both workers and capitalists are thought to be subject to non-arbitrary wills: those shaped by impersonal market imperatives. Similarly, Thompson suggests neo-republicans do not sufficiently appreciate "the functional logic of the economy", whereby workers are "dependent less on the individual capitalist than on the structure of extractive power". ${ }^{42}$

Consider a simplified example of such concerns. Owners and managers of private companies cannot act entirely at their own discretion indefinitely, since competitive pressures will drive them out of business if they are not heavily steered by profit-maximisation. For instance, in wage-setting, the need to retain their workforces and maintain long-term 
profitability means that employers cannot act with complete impunity even within the bounds of the labour contract and employment laws, since well-functioning markets will punish those who either dote upon or drive away staff.

Does such market discipline render radical republican analyses of capitalist economies moot? Not so. There is still room for considerable arbitrary power even within the strictures of the market. Writing in 1887 about the condition of women wage-workers in America, the social reformer Helen Campbell observed:

The swarming crowd of applicants are absolutely at the mercy of the manager or foreman, who, unless there is a sudden pressure of work, makes the selections according to fancy ${ }^{43}$

We see some market constraints operating here ("unless there is a sudden pressure of work") but also great discretionary power in the ordinary case, which places these women at the foreman's whim. Republicanism makes good sense of why even those women who do happen to be offered work are nonetheless exposed to considerable unfreedom by their precarity.

Furthermore, market incentives and deterrents are often flexible: the capitalist might decide to take a hit to their economic interests in any solitary case in which they would like to impose their will, even if a sustained disregard for market discipline would prove disastrous. Nor is it impossible for especially vengeful or incompetent employers to risk the fates of their organisations to pursue vendettas or indulge their own vanity. You can buck the market - even if you cannot always do so costlessly or systematically. The residual possibility of being targeted leaves workers subject to arbitrary power when they could still be at the sharp end of their employer's displeasure in any particular case.

Could this be a reason to intensify market discipline until much of this residual unaccountable power evaporates? The hope would be to supplant the remaining arbitrary power 
of individual owners and managers of productive property by forcing economic decisionmaking to even more closely track faceless market imperatives. Some radical republicans would say this simply confronts us with an "impersonal domination embodied in the market" afflicting capitalists and workers alike. ${ }^{44}$ Yet, this risks severing the conceptual connection between domination and another agent's arbitrary will - although the case might still be made for viewing "the market as a system for aggregating arbitria" ${ }^{45}$ In any case, even if ramping up market discipline could eliminate economic domination, this would still come at the cost of usurping economic agency from workers. ${ }^{46}$ Subordinating employer control to market competition need not create worker control. Thus, radical republicans should reject this strategy all the same.

\section{Private Government}

Can radical republicans offer an effective programme to combat economic domination? Elizabeth Anderson recapitulates much of the radical republican analysis of economic power but recommends milder measures than socialism. She has sought to show how contemporary workplaces are subject to regimes of "private government", which is "government that has arbitrary, unaccountable power over those it governs". ${ }^{47}$ Private government in the workplace is said to produce a "state of republican unfreedom, of subjection to the arbitrary will of another". ${ }^{48}$ Anderson provides a battery of examples showing how this control over workers manifests itself: from pressure from employers to support particular political causes and candidates, to subjecting retail workers to invasive anti-theft inspections on unpaid time, mandating suspicionless drug screening, firing union members, and cracking down on the 'time theft' represented by casual chatting. ${ }^{49}$ In response, "The task is to replace private government with public government". 50 
Anderson makes a number of proposals for reducing the domination of workers, including measures to secure exit options, rule of law, and just workplace constitutions. ${ }^{51}$ These include strong legal presumptions against 'noncompete' clauses, which contractually restrict workers' abilities to exit for other jobs in the same industry. Likewise, Anderson proposes strengthening analogues of the rule of law and constitutional protections within workplaces, through intrafirm complaints procedures, "employee handbooks and standard practice guides that streamline authority along legalistic lines", and basic workplace rights to free speech and non-discrimination. ${ }^{52}$

While each of these measures would be welcome, there remain grounds for doubting their sufficiency. Consider the codification of employer authority in employee handbooks. Unless this is accompanied by independently adjudicated sanctions for departing from intrafirm procedures, the codification of intrafirm practices will be unlikely to effectively restrain managerial power. Furthermore, the ability of managers and owners to revise these procedures at will without consulting workers makes them an even flimsier check on arbitrary power. These concerns about a lack of independent evaluation, enforcement, and establishment of rules internal to firms are echoes of Marx's criticisms of the "factory code", through which the capitalist exercises "like a private legislator, and at his own good will, his autocracy over his workpeople, unaccompanied by that division of responsibility, in other matters so much approved of by the bourgeoisie". ${ }^{53}$ Similarly, when responsibility for interpreting, implementing, and instituting organisational procedures circumscribing managerial power rests either in the hands of management themselves or the owners who appointed and can dismiss them, then workers do not enjoy an effective analogue of the rule of law.

Anderson's most dramatic proposal is for worker participation in management. It aims to significantly amplify worker 'voice', and so can seem well-placed to rebut our initial concerns over excessive concentrations of workplace power in the hands of employers. 
Anderson does not defend any particular model of participation but gestures approvingly towards German-style codetermination in which workers are represented on the boards of large companies. ${ }^{54}$ However, a more fundamental shift in the ownership and control of wealth and productive property is needed to definitively overturn class domination and worker unfreedom. Domination is resilient, and limited support for exit, law, and constitution, even in the context of codetermination, will leave much of it untouched. Why is this?

Codetermination leaves decisive power in the hands of shareholders, with even the extensive German Mitbestimmung system giving worker representatives only between a third and a little under a half of the votes on the supervisory boards of most large companies ${ }^{55}$ No individual shareholder acting alone can usually impose their arbitrary will, but shareholders acting together around aligned interests will prevail in the boardroom. Sympathetic critics admit that "even a minority presence can help strengthen workers' voice in corporate decisionmaking", but they note that the influence of codetermination institutions like supervisory boards and works councils is often limited to employment issues rather than the investment and strategy decisions made by separate management boards, such that "the more strategic the issue for management, the weaker the powers of the councils". 56

Shareholders can also use subtler techniques to resist worker control, such as altering the capital structure of the firm through debt leveraging, thereby restricting liquidity that workers might otherwise attempt to capture for wage rises or other worker-led projects ${ }^{57}$ Let us imagine a more ambitious system of codetermination can be devised which makes these schemes less likely by rebalancing worker and shareholder control. The ownership rights of shareholders will nevertheless constitute a hard limit on worker power within codetermining firms, with the threat of discretionary capital withdrawal and liquidation able to discipline workers. ${ }^{58}$ Thus, the ownership of firms cannot be easily disentangled from dominating control over them. 
While codetermination may modestly increase worker voice within a firm, it does little for those outside the organisation when it goes unmatched by wider democratic control over the economy. For instance, consumers are still beholden to the decisions of codetermining firms, with no more control over the supply of many essential goods and services - which can be altered, priced up, or withdrawn arbitrarily - than the incentive provided by access to their wallets. Similarly, jobseekers who lack economic independence will remain subject to the arbitrary power of managers throughout the process of hiring and contract negotiation. Consequently, the further danger with a codetermination-led strategy is not only that it will fail to sufficiently check domination internal to the firm, but that it can also leave citizens outside the firm at the mercy of those within it.

\section{Socialist Means, Republican Ends}

Socialism secures the grounds for a much deeper democratisation of the economy. Public ownership of the means of production establishes a stronger authority for transferring power to workers and citizens than policies like codetermination do. For instance, it would allow the introduction of democratic workplace constitutions which required those in managerial roles to be appointed by and be accountable to the rest of the workforce (a measure that existing managers, proprietors, and shareholders would doubtless veto under codetermination). The rationale for such policies is that managerial domination is held in check to the degree that managers are answerable to those over whom they hold power. Public ownership also provides an opportunity for a more radical transformation of the internal social structure of workplaces to enable workers themselves to assume more autonomy (and not simply to have more say in who has authority over them). When private shareholders and owners are displaced, this allows a slackening of the relentless pursuit of profit-maximisation - which, in turn, creates greater scope for employees to organise their working lives in ways that suit them, rather than being 
subjected to a regime that squeezes the utmost economic value from their time. This second strategy does not attempt to make managerial power over workers less arbitrary but rather transfers much of this power directly to workers themselves.

Public ownership of the means of production does not, however, mean there are no external pressures on workers. Private shareholders and proprietors are replaced by social ownership by the citizenry and other stakeholders, through which democratic authority can be exerted. This gives society at large some control over both the goals which are set for an industry and the investments it receives. Such a fundamental shift in power would allow the focuses of economic life - say, whether to concentrate on climate change mitigation or reducing the cost of consumer goods - to be set by the democratic will and not the desires of private owners of capital. The citizenry would no longer be subordinated to the whims and interests of a capitalist class and could instead set its own direction of economic travel. Furthermore, economic surpluses not needed for reinvestment would remain in public hands, and subject to democratic authority. These could be used to strengthen health, education, criminal justice, and welfare provisions - not only in order to bring direct benefits to citizens, but so as to better equip them to resist private domination by partners, relatives, or acquaintances, and public domination by officials or other figures with social authority.

Citizen control over the economy does not have to presuppose high barriers to citizenship which would horde economic freedoms for existing citizens and deny them to migrants. Even republican thinkers like Hannah Arendt, who notes there is no precedent for free and equal relationships which are not "spatially limited", have observed that this does not preclude the establishment of a "community of interest with the oppressed and exploited", which emerges "out of solidarity", and encompasses "not only the multitude of a class or a nation or a people, but eventually all mankind." 59 The civic economic democracy of socialist republicanism can share this solidaristic, porous, and inclusive character. 
The core idea driving socialist republicanism is that public ownership of the means of production would offer an institutional foundation for widespread freedom without domination. Public ownership underpins democratic control, which can be used to ensure that access to many of the background conditions necessary to enjoy meaningful citizenship is not dependent on the arbitrary will of a particular individual or class. Of course, economic democracy is not a panacea. ${ }^{60}$ Democratic institutions can still be captured by factional interests and ride roughshod over minorities, especially in the absence of a broader egalitarian ethos and mechanisms for oversight and review. Furthermore, democratic control of the citizenry over the economy as a whole can stand in tension with the democratic control of specific groups of employees over their own workplaces. Thus, there is a need to think seriously about what institutional structures can do sufficient justice to both dimensions of economic democratisation. ${ }^{61}$ It is also important to recognise that a socialist republicanism narrowly focused on economic domination is not a sufficient response to domination grounded in gender and race, which have distinctive recognitive as well as economic dimensions. ${ }^{62}$ Nevertheless, socialist republicans hold that worker and citizen control of the economy are among the fundamental conditions for forestalling endemic personal and structural domination.

\section{Property-Owning Democracy}

Is fighting for socialism on republican grounds using a sledgehammer to crack a nut? We might think public ownership is unnecessary, and effective social control over wealth is sufficient for non-domination. Such control could be achieved by dispersing private ownership widely among individuals rather than concentrating it in the hands of a democratic state or community. This is the vision animating Rawlsian property-owning democracy, whose background institutions are intended to "disperse the ownership of wealth and capital, and thus to prevent a small part of society from controlling the economy, and indirectly, political life as well.",63 
Property-owning democracy has also been defended by liberal republicans such as Alan Thomas, who tells us that capital-ownership in particular, "increases independence from 'undue influence' and domination by others". ${ }^{64}$ These property-owning democrats want to spread private wealth widely instead of taking it into public ownership, and they favour an initial predistributive diffusion of wealth and human capital over redistribution of incomes. Indeed, there is an earlier radical republican precedent for such a position in William James Linton's The English Republic, which attacks "the monstrous relationship of master and servant-employer and employed, profitmonger and wages slave", while simultaneously denying that "private property is inevitably a nuisance". ${ }^{65}$ He continues: "Our complaint is not that there is too much individual property, but that there is too little; not that the few have, but that the many have not."

Why not, then, opt for property-owning democracy as a method of securing greater independence from both private employers and the designs of the state? Firstly, its commitment to democracy remains narrowly political, such that Rawls himself observes that a propertyowning democracy does not itself establish workplace democracy. ${ }^{66}$ Admittedly, nor does it preclude democratic control of workplaces secured through private means, such as workerowned cooperatives. Yet, as critics of property-owning democracy such as Nien-hê Hsieh point out, there are obstacles to forms of democratisation grounded in worker-ownership, especially in the context of large-scale or capital-intensive economic enterprises. ${ }^{67}$ Workers can own some share of their workplace while its internal constitution remains undemocratic - earning them dividends but little effective control as small stakeholders.

Even if democratic governance within workplaces is achieved, there are significant costs to securing social control over economic life through property-owning democracy rather than socialist public ownership. For instance, worker-ownership leaves workers doubly exposed to the failure of firms, since they lose much of their capital when they lose their jobs 
- the very time when they would most need to draw on it. The welfare state might still act as a social safety net in such cases, but this suggests the dual independence from corporate and state power that property-owning democracy was meant to achieve is at best partial. Furthermore, worker-ownership crowds out democratic control by the citizenry at large, thereby economically disenfranchising those who are retired, informal carers, or unable to work. In other words, if control is secured through worker-ownership, then those outside formal employment will have significantly less influence over our shared economic life than others.

Public ownership is a more reliable route to both the socialisation of economic risk and democratic control over the productive economy. Similar lessons apply to the socially reproductive goods needed to make and remake people. For instance, dispersal of assets through widespread private home ownership leaves homeowners individually exposed to the vicissitudes of the housing market - including both precipitous declines in asset prices and unearned windfalls. Public housing not only avoids these problems but can be planned, developed, maintained, and distributed democratically, without housing provision being beholden to the wills of those with private capital. Thus, there is good reason to socialise much productive and reproductive property alike.

\section{Public Domination}

Will socialising rather than dispersing private property simply replace private domination with public domination? Jeffrey Reiman warns, "If ownership of means of production is the main source of coercive power in a society, Marxists above all should be wary of placing that ownership in the hands of any single institution, much less the state with its police and its armies." ${ }^{98}$ These concerns have also been raised by republican thinkers, with Alan Thomas favouring property-owning democracy over market socialism on similar grounds. He tells us 
that "dispersed power supports polyarchic governance and thereby protects individual freedom". ${ }^{69}$ But the most sustained warnings have come from the commercial republican Robert Taylor, who is always quick to remind us that "state domination remains an ever-present risk". ${ }^{70}$

Taylor considers whether "the state could try to empower voice directly", through "generally rebalancing economic power in favor of labor", or "requiring companies to have German-style works councils or other forms of labor participation in managerial decisions". ${ }^{71}$ He rejects such policies on the grounds that they "necessarily give a great deal of discretionary power to (quasi-)public agents, power that can and will be frequently abused for non-public ends." 72 Taylor's concern is that using the apparatus of the state to directly quash domination - rather than merely increasing exit options within potentially dominating relationships inevitably has the perverse result of intensifying aggregate domination. Thus, in bearing down on private domination so directly, we are thought to rely on greater concentrations of publicly dominating arbitrary power. Among the dangers that Taylor identifies is the "quasi-public power $[\ldots]$ of the state itself in its pursuit of industrial democracy or even associational socialism", and these worries are sure to loom larger still if such a state also holds and controls productive property. ${ }^{73}$ Why, then, think the juggernaut of the state is going to be any less dominating than the owners of private capital?

The most important distinguishing characteristic is the state's subjection to comprehensive democratic control by the citizen body. Neo-republicans have argued that democratic governance under a mixed constitution and supported by a vigilant citizenry can create conditions for "government that would promote the equal freedom of citizens without itself becoming a master in their lives - in other words, that would protect against private forms of domination without perpetrating public forms." ${ }^{, 74}$ It is true that political democracy and civic contestation render the collective power of citizens over themselves less arbitrary. But we 
cannot rest content with a mere appeal to a democratic republican state and civic culture as a bulwark against socialist public domination, since the complex and untidy operations of any real state are bound to create countless small enclaves of arbitrary power which are somewhat resistant to meaningful democratic oversight and control through centralised state institutions. Socialist republicans should not brush these dangers away by adverting to some ideal macropolitical constitutional or institutional framework which is supposed to render economic domination impossible. Instead, the healthier response is to consider which political and economic forms and practices are likely to minimise dominating relationships that might arise through a larger economic role for the state, and what measures can be taken to mitigate the economic domination that remains.

The first such measure is to ensure citizens have unconditional access to an economic minimum. Someone with an ability to meet their basic material needs which is contingent on neither the good will of state nor market actors enjoys significant economic independence, which allows them to resist pressure to conform to the designs of others. This could take the form of both an unconditional basic income and unconditional basic services, such as education, healthcare, and housing. ${ }^{75}$ The unconditionality of these provisions is important, because it reduces the circumstances in which other agents will possess the discretionary power to determine whether someone's fundamental needs are met, and thereby closes down the dominating social power this can introduce. ${ }^{76}$ Even under a highly statist socialism in which access to employment and the resources required to pursue productive and reproductive economic projects were controlled by a centralised decision-making bureaucracy, then the provision of an unconditional economic minimum would act as a significant counterweight to potential state domination.

The second response to the danger of public domination begins by pushing back against an overly narrow construal of public ownership which supposes that such a centralised state 
socialism is the only model available. There remains scope for nationalisation of industry and infrastructure under socialism, especially where horizontal integration can deliver significant efficiencies of scale that redound to the public good. However, the monopolistic and monopsonist dangers of such economic concentration cannot be ignored by those socialist republicans attentive to the threat of public domination. Socialists have been sensitive to these worries, with many rejecting a top-down 'Morrissonian' approach to nationalisation whereby a government simply appoints an official with instructions to run the nationalised service in the public interest. ${ }^{77}$ Instead, these socialists often recommend forms of nationalisation which combine democratic governance by the workforce, the users of the service, and the citizen body as a whole - balancing the effective power of several stakeholders who can keep each other's potentially dominating power in check. ${ }^{78}$ Nor is nationalisation itself the only kind of public ownership available to socialist republicans. Municipal ownership, community enterprises, and development trusts each offer more local forms of public ownership and control over productive and reproductive property, which do not concentrate economic authority in the hands of central government. ${ }^{79}$ Socialist republicans can advocate a multiplicity of public ownership structures at various scales, while seeking to promote a diverse ecology of state and non-state organisations able to disperse power, so that no individual, official, or group amasses dangerous levels of unaccountable authority.

How do we get there from here? The immediate and forceable expropriation of all private productive and reproductive property by a socialist republican state is not likely to allay fears about public domination. Socialists have proposed alternative models for democratising the economy, however, such as the use of 'public-commons partnerships', which create governance and capitalisation structures for joint economic enterprises that bring together state agents, stakeholders from civil society, and members of 'commons associations'. ${ }^{80}$ They are designed to decentralise democratic control, while ensuring a share of surplus value created 
within them is used to support other such partnerships in a "self-expanding circuit" ${ }^{81}$ Other incrementalist policies for socialising productive wealth are also available, such as inclusive ownership funds, which compel or strongly incentivise private firms to deposit a modest share of annual profits, in the form of equity, in worker- or publicly-controlled funds. ${ }^{82}$ Socialist economic programmes along these lines - which solicit support from allied state power without pursuing a centralised statist command economy - have the potential to combat private economic domination without substituting greater public domination. Likewise, they stand in contrast to militant plans for revolutionary cadres to overthrow or seize control of the state. Nevertheless, socialist republicans should not be naïve about the forces that would be massed against any attempt to socialise vast tracts of private property, and should recognise the need to build sufficient social power to repel potentially violent attempts to disrupt their projects. ${ }^{83}$

\section{Conclusion}

Let us recapitulate the case for socialist republicanism. The republican tradition has been attacked for its elitism and conservatism - something which we considered under the headings of private property, disenfranchisement, and a latter-day support for markets. We saw, however, that none were essential features of a recognisable republicanism. Looking to the nineteenth-century, it became clear that republican conceptual resources could be turned to radical political ends, in the forms of robust socialism or working class cooperativism. Our aim has been not only to add a new historical chapter to this story, which shows how the radical republican tradition extends into the twentieth century, but to develop a forward-looking programmatic account of socialist republicanism. This means confronting a number of conceptual and institutional problems that historians of radical republicanism like Gourevitch have not addressed at length - such as, the challenge posed by non-republican Marxism, if codetermination is sufficient for non-domination, whether radical republicans should embrace 
property-owning democracy, and what forms of public ownership are required to keep economic domination at bay.

The concern that republicanism could not accommodate a cardinal insight of Marxist politics - that systemic factors are more important than the human will - was ultimately not founded, since arbitrary power still abounds even when people are restrained in other respects by impersonal market forces. Distinctively socialist republicanism arises not only from a diagnosis of economic domination but a particular programme for combatting it, which is rooted in public ownership of productive and reproductive property. The objection that this programme is needlessly maximalist and avoids attractive alternatives in codetermination or property-owning democracy was rebutted by pointing to democratic deficits in these more limited proposals, as well as significant individualisation of economic risk in strategies retaining high levels of private property. Finally, we saw that public ownership did not entail a publicly dominating concentration of property in the hands of the state, with new institutional forms such as public-commons partnerships and inclusive ownership funds allowing a decentralisation of democratic control.

In sum, the case for socialist republicanism is that socialism provides a strong institutional basis for combatting domination and that republicanism provides a strong conceptual basis for articulating the economic unfreedom rife in capitalist society. How does socialism tackle domination? Public ownership of productive property is a vehicle for both democratic control over firms and worker control within them. This provides a check on the arbitrary power currently held by managers, owners, and shareholders, who have sweeping discretion to impose their own will on workers and consumers. Socialist welfare provisions also strengthen the hand of non-workers by providing less conditional access to the resources and skills needed to resist domination in the home and the public sphere. Conversely, republicanism itself provides the theoretical apparatus for diagnosing the threat to freedom 
constituted by arbitrary managerial power and class-based domination. The positive goal of achieving a solidaristic and relational economic independence - which ensures that people are not thoroughly exposed to the caprice of others in their personal and civic lives - is a worthy goal for an emancipatory socialist politics. Thus, socialist republicanism offers a compelling analysis of economic life under capitalism and a plausible programme for beginning to rectify its flaws.

1 John McCormick, "Machiavelli Against Republicanism: On the Cambridge School's Guicciardinian Moments," Political Theory 31:5 (2003), 615-643; Clifford Ando, "A Dwelling Beyond Violence': On the Uses and Disadvantages of History for Contemporary Republicans," History of Political Thought 31:2 (2010), 183-220; John McCormick, "Republicanism and Democracy," Republican Democracy: Liberty, Law and Politics, Andreas Niederberger and Philipp Schink (eds.) (Edinburgh University Press, 2013), 89-127; Manjeet Ramgotra, "Conservative Roots of Republicanism," Theoria: A Journal of Social and Political Theory 61:139 (2014), 22-49; John McCormick, “The New Ochlophobia? Populism, Majority Rule and Prospects for Democratic Republicanism," Republicanism and the Future of Democracy, Yiftah Elazar and Geneviève Rousselière (eds.) (Cambridge: Cambridge University Press, forthcoming).

2 Ando, "A D Dwelling Beyond Violence"”, 185; Alex Gourevitch, From Slavery to the Cooperative Commonwealth: Labor and Republican Liberty in the Nineteenth Century (Cambridge: Cambridge University Press, 2015), ch. 1.

${ }^{3}$ See $\$ 2$ for further details. For other objections alleging republicanism is retrogressive, see Robert Goodin, “Folie Républicaine,” Annual Review of Political Science 6 (2003), 55-76. 
${ }^{4}$ Some neo-republicans even want to keep 'romantic' republican thinkers like Jean-Jacques Rousseau at arm's length for similar reasons. See Philip Pettit, "Republicanism and Democracy," Republican Democracy: Liberty, Law and Politics, Andreas Niederberger and Philipp Schink (eds.) (Edinburgh University Press, 2013), 169-204.

${ }^{5}$ Alex Gourevitch, "Labor Republicanism and the Transformation of Work," Political Theory 41:4 (2013), 591-617; Alex Gourevitch, From Slavery to the Cooperative Commonwealth: Labor and Republican Liberty in the Nineteenth Century (Cambridge: Cambridge University Press, 2015); William Clare Roberts, Marx's Inferno: The Political Theory of Capital (Princeton: Princeton University Press, 2017); Bruno Leipold, Citizen Marx: The Relationship between Karl Marx and Republicanism (PhD thesis, University of Oxford, 2017); Michael Thompson, "The Radical Republican Structure of Marx's Critique of Capitalist Society," History of Political Thought (forthcoming); Bruno Leipold, 'Chains and Invisible Threads: Liberty and Domination in Marx's Account of Wage Slavery', Rethinking Liberty Before Liberalism, Hannah Dawson and Annelien de Dijn (eds.) (Cambridge: Cambridge University Press, forthcoming).

${ }^{6}$ Stuart White, "The Republican Critique of Capitalism," Critical Review of International Social and Political Philosophy 14:5 (2011), 561-79; Iñigo González-Ricoy, “The Republican Case for Workplace Democracy," Social Theory and Practice 40:2 (2014), 232-254; Ruth Yeoman, Meaningful Work and Workplace Democracy: A Philosophy of Work and a Politics of Meaningfulness (Basingstoke: Palgrave Macmillan, 2014), ch 4; Keith Breen, "Freedom, Republicanism, and Workplace Democracy," Critical Review of International Social and Political Philosophy 18:4 (2015), 470-85; David Casassas and Jurgen De Wispelaere, "Republicanism and the Political Economy of Democracy," European Journal of Social Theory 19: 2 (2016), 283-300; Alex Gourevitch, "The Right to Strike: A Radical View," American Political Science Review 112:4 (2018), 905-17; Iñigo González-Ricoy, “Ownership 
and Control Rights in Democratic Firms - A Republican Approach," Review of Social Economy (2019), doi: 10.1080/00346764.2018.1552792; Alex Bryan, "The Dominating Effects of Economic Crises", Critical Review of International Social and Political Philosophy (2019), doi: 10.1080/13698230.2019.1581492.

${ }^{7}$ Iseult Honohan, Civic Republicanism (London: Routledge, 2002), 5-6.

${ }^{8}$ McCormick, "Machiavelli Against Republicanism”, 615.

${ }^{9}$ Cicero, On Duties, M.T. Griffin and E.M. Atkins (eds.) (Cambridge: Cambridge University Press, 1991), II.74, 93.

${ }^{10}$ Cicero, On Duties, II.78, 95.

${ }^{11}$ James Harrington, The Commonwealth of Oceana and A System of Politics (Cambridge: Cambridge University Press, 1992), 75.

${ }^{12}$ Algernon Sidney, Discourses Concerning Government (London: J. Darby, 1704), II.5, 69.

${ }^{13}$ Sidney, Discourses Concerning Government, III.41, 397.

${ }^{14}$ Robert Taylor, Exit Left: Markets and Mobility in Republican Thought (Oxford University Press, 2017), 52; Robert Taylor, "Republicanism and Markets", Republicanism and the Future of Democracy, Yiftah Elazar and Geneviève Rousselière (eds.) (Cambridge: Cambridge University Press, forthcoming), 196-212, 202.

${ }^{15}$ Taylor, Exit Left, 62-3.

${ }^{16}$ Philip Pettit, "Freedom in the Market," Politics, Philosophy, \& Economics 5:2 (2006), 131$49,142$.

${ }^{17}$ Pettit, "Freedom in the Market," 142.

${ }^{18}$ Philip Pettit, Just Freedom: A Moral Compass for a Complex World (New York: W.W. Norton \& Company, 2014), 91.

${ }^{19}$ Sam Gindin, "Socialism for Realists," Catalyst 2:3 (2018). 
${ }^{20}$ While I have opted to begin on the familiar ground of Marx, it is worth noting a recent attempt to identify a feminist socialist republicanism in the work of Flora Tristan in the midnineteenth century: Kevin Duong, "No Social Revolution Without Sexual Revolution," Political Theory (2019), doi: 10.1177/0090591719829061, 1-27.

${ }^{21}$ Karl Marx and Friedrich Engels, Manifesto of the Communist Party, reprinted in Collected Works 6 (London: Lawrence \& Wishart, 1976), 491; Karl Marx, Economic and Philosophic Manuscripts of 1844, reprinted in Collected Works 3 (London: Lawrence \& Wishart, 1975), 280; Karl Marx, Capital: A Critique of Political Economy (vol. 1), reprinted in Collected Works 35 (London: Lawrence \& Wishart, 1996), 715; Karl Marx, The Civil War in France, reprinted in Marx Engels Collected Works 22 (London: Lawrence \& Wishart, 1986), 307-359, 497. For further discussion of the social republic, see Jason Schulman, "Socialism: Liberal or Democratic-Republican?" in Rational Radicalism and Political Theory: Essays in Honor of Stephen Eric Bronner, Michael Thompson (ed.) (Lanham: Lexington Books, 2010), 189-206, 199; Bruno Leipold, 'Social Republic', Krisis: Journal for Contemporary Philosophy 2 (2018).

The most rigorous and well-evidenced of Marx's relationship to republicanism is Leipold, Citizen Marx, and I draw heavily on its textual scholarship in the following paragraphs. See also Roberts, Marx's Inferno. On Marx's relationship to republicanism in a more capacious sense, see Jeffrey Isaac, “The Lion's Skin of Politics: Marx on Republicanism” Polity 22:3 (1990), 461-488 and Thompson, "The Radical Republican Structure of Marx's Critique of Capitalist Society".

${ }^{22}$ Auguste Blanqui, Social Wealth Must Belong to Those Who Created It (Le Libérateur no. 2, February 1834) (London: The Blanqui Archive, undated), Philippe Le Goff, Peter Hallward, and Mitchell Abidor (trans.), available: https://blanqui.kingston.ac.uk/texts/social-wealthmust-belong-to-those-who-created-it-february-1834/ See Leipold, 'Chains and Invisible Threads'. 
${ }^{23}$ Friedrich Engels, The Condition of the Working-Class in England, reprinted in Collected Works 4 (London: Lawrence \& Wishart, 1975), 379.

${ }^{24}$ Marx, Capital, 639.

${ }^{25}$ Marx and Engels, Manifesto, 491.

${ }^{26}$ Engels, Condition of the Working-Class, 442.

${ }^{27}$ See Michael Sandel, Democracy's Discontent: America in Search of a Public Philosophy (Cambridge, MA: Harvard University Press, 1996), ch. 5-6 and Gourevitch, From Slavery to the Cooperative Commonwealth.

28 “Slavery," Journal of United Labour 3:2 (June 1882), 248; Sidney, Discourses, III.21, 319.

29 “Wages Slavery and Chattel Slavery,” Journal of United Labor 5:2 (1884), 702.

${ }^{30}$ S. M. Jelley, The Voice of Labor (Chicago: A. B. Gehman \& Co, 1887), 279.

${ }^{31}$ Gourevitch, From Slavery to the Cooperative Commonwealth, 109.

${ }^{32}$ For alternative capabilitarian accounts of structural domination, see Rutger Claassen and Lisa Herzog, "Why Economic Agency Matters: An Account of Structural Domination in the Economic Realm," European Journal of Political Theory (2019), doi:10.1177/1474885119832181; Tom O’Shea, “Are Workers Dominated?” Journal of Ethics and Social Philosophy (forthcoming), §8.

${ }^{33}$ Gourevitch, "Labor Republicanism and the Transformation of Work", 602, 596

${ }^{34}$ Gourevtich, From Slavery to the Cooperative Commonwealth, ch. 4-5.

${ }^{35}$ Eugene Debs, “The Social Democratic Party,” The Independent [New York] 52: 2699 (Aug. 23, 1900), 2018-21.

${ }^{36}$ Eugene Debs, “The National Platform Explained," Social Democratic Herald 5:4:208 (July 26, 1902), 1

${ }^{37}$ George McNeill, "Declaration of the Principles of the K. of L.”, The Labor Movement; The Problem of To-Day, George McNeill (ed.) (New York: M.W. Hazen Co, 1887), 456. 
${ }^{38}$ Sidney and Beatrice Webb, Industrial Democracy (London: Longmans, Green, and Co, 1897), 841.

39 R.H. Tawney, The Acquisitive Society (London: G. Bell and Sons, 1921), 93; Philip Snowden, "Twenty Objections to Socialism," (London: Independent Labour Party, 1920), 2. See Ben Jackson, Equality and the British Left: A Study in Progressive Political Thought, 190064 (Manchester: Manchester University Press, 2007), 22-7.

${ }^{40}$ Marx, Capital, 276.

${ }^{41}$ Nicholas Vrousalis, "Freedom and republicanism in Roberts' Marx," Capital \& Class 41:2 (2017), 378-3, 381.

42 Michael Thompson, "Reconstructing Republican Freedom: A Critique of the NeoRepublican Concept of Freedom as Non-Domination," Philosophy and Social Criticism 39:3 (2013), 277-98, 288.

${ }^{43}$ Helen Campbell, Prisoners of Poverty: Women Wage-Workers, Their Trades and Their Lives (Boston: Little, Brown, and Company, 1887), 35.

${ }^{44}$ Roberts, Marx's Inferno, 102.

${ }^{45}$ Roberts, Marx's Inferno, 93.

46 On the distinction between usurpation and domination, see Patchen Markell, "The Insufficiency of Non-Domination," Political Theory 36:1 (2008), 9-36.

${ }^{47}$ Elizabeth Anderson, Private Government: How Employers Rule Our Lives (and Why We Don't Talk About It) (Princeton: Princeton University Press, 2017), 45. See also Elizabeth Anderson, "Equality and Freedom in the Workplace: Recovering Republican Insights," Social Philosophy and Policy 31:2 (2015), 48-69.

${ }^{48}$ Anderson, Private Government, 64.

${ }^{49}$ Anderson, Private Government, xix.

${ }^{50}$ Anderson, Private Government, 65. 
${ }^{51}$ Anderson, Private Government, 65-66.

${ }^{52}$ Anderson, Private Government, 66-8.

53 Marx, Capital, 427.

${ }^{54}$ Anderson, Private Government, 70.

55 Gary Gorton and Frank Schmid, "Class Struggle Inside the Firm: A Study of German Codetermination”, NBER Working Paper No. w7945 (2000), 9-10.

${ }^{56}$ Richard Hyman, “The Very Idea of Democracy at Work”, Transfer: European Review of Labour and Research 22:1 (2016), 12-24, 15.

57 David Matsa, "Capital Structure as a Strategic Variable: Evidence from Collective Bargaining", The Journal of Finance 65:3 (2010), 1197-232; Gorton and Schmid, "Class Struggle Inside the Firm”, 27-8.

${ }^{58}$ Hyman, “The Very Idea of Democracy at Work”, 17.

${ }^{59}$ Hannah Arendt, On Revolution (London: Penguin, 1963), 275, 88.

${ }^{60}$ For discussion of some key objections, see Robert Dahl, A Preface to Economic Democracy (Berkeley: University of California Press, 1985).

${ }^{61}$ For proposals to navigate such tensions, see Karl Polanyi, "On Freedom," reprinted in Economy and Society: Selected Writings, Claus Thomasberger and Claus Thomasberger and Michele Cangiani (eds.), 15-40 and James Muldoon (ed.), Council Democracy: Theorising Boundaries between the Political and Economic (London: Routledge, 2018).

${ }^{62}$ Nancy Fraser, "From Redistribution to Recognition? Dilemmas of Justice in a 'PostSocialist' Age”, New Left Review 212 (1995), 68-93.

${ }^{63}$ John Rawls, Justice as Fairness: A Restatement (Cambridge, MA: Harvard University Press, 2001), 139.

64 Alan Thomas, Republic of Equals: Predistribution and Property-Owning Democracy (Oxford: Oxford University Press, 2017), 146. 
${ }^{65}$ William James Linton, The English Republic (London: Swan, Sonnenschein \& Co, 1891), 48 and 12.

${ }^{66}$ Rawls, Justice as Fairness, 178.

${ }^{67}$ Nien-hê Hsieh, "Work, Ownership, and Productive Enfranchisement," in Martin O’Neill and Thad Williams (eds.), Property-Owning Democracy: Rawls and Beyond (Hoboken: WileyBlackwell, 2014), 149-62, 152.

${ }^{68}$ Jeffrey Reiman, As Free and as Just as Possible: The Theory of Marxian Liberalism (Oxford: Wiley-Blackwell, 2012), 15.

${ }^{69}$ Thomas, Republic of Equals, 217.

${ }^{70}$ Taylor, Exit Left, 8.

${ }^{71}$ Taylor, Exit Left, 6.

${ }^{72}$ Taylor, Exit Left, 6.

${ }^{73}$ Taylor, Exit Left, 102.

${ }^{74}$ Philip Pettit, On the People's Terms: A Republican Theory and Model of Democracy (Cambridge: Cambridge University Press, 2012), 6.

75 There are some defences of universal basic income on republican grounds, such as Philip Pettit, “A Republican Right to Basic Income?", Basic Income Studies 2:2 (2007), 1-8. However, some radical republicans urge caution here: Alex Gourevitch and Lucas Stanczyk, “The Basic Income Illusion”, Catalyst 1:4 (2018).

${ }^{76}$ O’Shea, “Are Workers Dominated?”, §5-6.

${ }^{77}$ Andrew Cumbers, Reclaiming Public Ownership: Making Space for Economic Democracy (London: Zed Books, 2012), ch. 1.

${ }^{78}$ Andrew Cumbers, "Renewing Public Ownership: Constructing a Democratic Economy in the Twenty-First Century", Centre for Labour and Social Studies Policy Paper (2014). 
79 “Alternative Models of Ownership", Report to the Shadow Chancellor of the Exchequer and Shadow Secretary of State for Business, Energy and Industrial Strategy (London: The Labour Party, 2017), 20-3.

${ }^{80}$ Keir Milburn and Bertie Russell, "What Can an Institution Do? Towards Public-Common Partnerships and a New Common-Sense", Renewal: A Journal of Social Democracy 26:4 (2018), 45-44; Keir Milburn and Bertie Russell, "Public-Common Partnerships: Building New Circuits of Collective Ownership", Common Wealth Report (2019), 1-27.

${ }^{81}$ Milburn and Russell, "Public-Common Partnerships", 17.

${ }^{82}$ Mathew Lawrence, Andrew Pendleton, and Sara Mahmoud, "Cooperatives Unleashed”, New Economics Foundation Report (2018), 41-2.

${ }^{83}$ The problem of egalitarian violence is especially acute in light of a recent study by Walter Scheidel, The Great Leveler: Violence and the History of Inequality from the Stone Age to the Twenty-First Century (Princeton: Princeton University Press, 2017). For a discussion of the asyet-unmet challenge it poses to radical republicanism, see Robert Taylor, "Delaboring Republicanism", Public Affairs Quarterly (forthcoming). 